
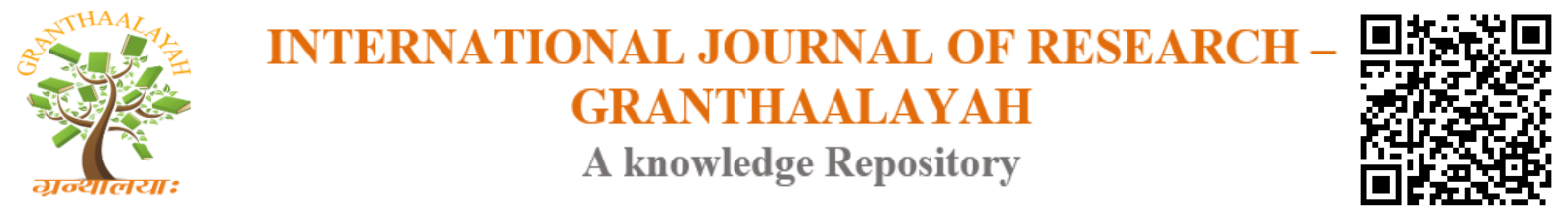

Social

\title{
ATTITUDE TOWARDS HOME WORK AMONG TEACHERS AT SECONDARY LEVEL IN COIMBATORE DISTRICT
}

\author{
R. Srirangam ${ }^{1}$, S.Mahendran ${ }^{2}$ \\ ${ }^{1}$ MCom., M.Ed Scholar, RVS College of education, Sulur, India \\ ${ }^{2}$ M.A., M.Ed, Assistant Professor in History Education, RVS College of Education, Sulur, India
}

DOI: https://doi.org/10.29121/granthaalayah.v5.i5(SE).2017.1973

\begin{abstract}
Homework is defined as a set of tasks assigned to students by their teachers to be completed outside the class. Common homework assignments may include a quantity or period of reading to be performed, writing or typing to be completed, problems to be solved, a school project to be built (such as a diorama or display), or other skills to be practiced. The study aimed to examine the attitude towards home work among teachers at secondary levels. The investigator adopted survey method to study the attitude towards home work among teachers at secondary levels. For this study a sample of 300 secondary level teachers from five Govt and Private schools which are situated in and around Coimbatore district in Tamil Nadu were selected by the investigator using simple random sampling technique. The findings reveal that is inferred that there is a difference in the level of attitude towards homework among school teachers at secondary level.
\end{abstract}

Keywords: Homework; Teachers; Investigator; Skils \& Attitude.

Cite This Article: R. Srirangam, and S.Mahendran. (2017). "ATTITUDE TOWARDS HOME WORK AMONG TEACHERS AT SECONDARY LEVEL IN COIMBATORE DISTRICT." International Journal of Research - Granthaalayah, 5(5)SE, 78-82. https://doi.org/10.29121/granthaalayah.v5.i5(SE).2017.1973.

\section{Introduction}

Homework is defined as a set of tasks assigned to students by their teachers to be completed outside the class. Common homework assignments may include a quantity or period of reading to be performed, writing or typing to be completed, problems to be solved, a school project to be built (such as a diorama or display), or other skills to be practiced. Almost every teacher assigns homework to students. Teachers, parents as well as students believe that this activity -which should be done in non-school hours-enhances achievement. The amount of time students spend doing homework has been the focus of national surveys and international comparisons. According to Kackar, Shumow, Schmidt \& Grzetichage (2011) age and gender are powerful influences in human development... and Time use is a fundamental indicator of cultural 
practices, values, and behavior. Kackar et al. (2011) argued that time spent doing homework is related to academic success (Schmitz \& Skinner, 1993). However, the empirical evidence of such association is not consistent (Cooper, Lindsay, Nye, \& Greathouse, 1998). The relation between school liking (or belonging or connectedness) and academic attainment is an important aspect of motivation. Belonging or connectedness to school has been perceived to be associated with pupil wellbeing and academic achievement. As positive attitudes toward homework are part of the sense of belonging to school, researchers have found very small correlation between attitudes homework and time spent on homework (Cooper et al., 1998).

\section{HYPOTHESIS: 1}

There will be a difference in the level of attitude towards homework among school teachers at secondary level.

Table 1: Frequency and percentage difference in the level of attitude towards homework among school teachers at secondary level.

\begin{tabular}{|c|c|c|c|c|c|c|c|c|}
\hline \multicolumn{9}{|c|}{ Attitude towards home work } \\
\hline \multicolumn{3}{|c|}{ Low } & \multicolumn{3}{|c|}{ Moderate } & \multicolumn{3}{|c|}{ High } \\
\hline Q1 & $\mathbf{F}$ & $\%$ & Q2 & $\mathbf{F}$ & $\%$ & Q3 & $\mathbf{F}$ & $\%$ \\
\hline 91 & 72 & $24 \%$ & 101 & 151 & $50.33 \%$ & 111 & 77 & $25.66 \%$ \\
\hline
\end{tabular}

Table 1 exhibits the result of attitude towards homework among school teachers at secondary level. According to the table totally $24 \%$ of the teachers at secondary level belong to low level of attitude towards home work, $50.33 \%$ of the teachers at secondary level belong to moderate level of attitude towards home work, and $25.66 \%$ of the teachers at secondary level belong to high level of attitude towards home work. So the hypothesis No: 1 is accepted. Thus it is inferred that there is a difference in the level of attitude towards homework among school teachers at secondary level.

\section{HYPOTHESIS: 2}

There will be a significant mean score difference in attitude towards homework among secondary level teachers based on gender.

Table 2: Mean score difference and t-test of attitude towards homework among secondary level teachers based on gender.

\begin{tabular}{|c|c|c|c|c|c|c|c|c|}
\hline S.NO & GENDER & $\mathbf{N}$ & Mean & S.D & df & t-value & p-value & Result \\
\hline 1. & MALE & 132 & 99.11 & 12.918 & \multirow{3}{*}{300} & \multirow{3}{*}{1.682} & \multirow{3}{*}{.314} & \multirow{3}{*}{ N.S } \\
\hline 2. & FEMALE & 168 & \multirow{2}{*}{101.69} & \multirow{2}{*}{13.366} & & & & \\
\hline 3. & TOTAL & 300 & & & & & & \\
\hline
\end{tabular}

The Table 2 shows that mean score difference in attitude towards homework among secondary level teachers based on gender. The calculated t-value is statistically not significant at 0.05 levels and hence, the hypothesis 2 is rejected. It can be concluded that there is no significant difference in attitude towards homework among secondary level teachers based on gender. 


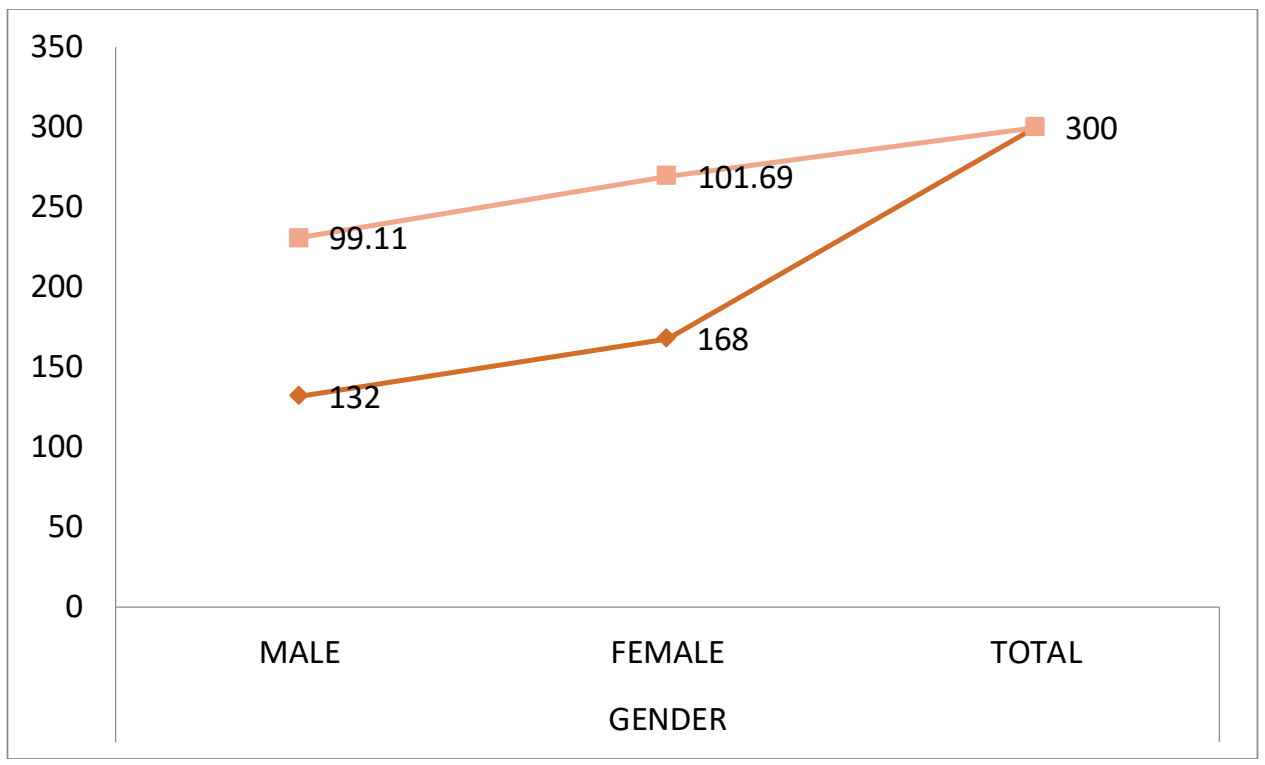

Chart 1: Mean Score Difference in Attitude towards Home Work among Teachers at Secondary Level Based on Gender

\section{HYPOTHESIS: 3}

There will be a significant mean score difference in attitude towards homework among secondary level teachers based on medium of instruction.

Table 3: Mean score difference and t-test of attitude towards homework among secondary level teachers based on medium of instruction.

\begin{tabular}{|c|c|c|c|c|c|c|c|c|}
\hline S.NO & $\begin{array}{l}\text { MEDIUM OF } \\
\text { INSTRUCTION }\end{array}$ & $\mathbf{N}$ & Mean & S.D & df & $\begin{array}{l}\text { t- } \\
\text { value }\end{array}$ & $\begin{array}{l}p \text { - } \\
\text { value }\end{array}$ & Result \\
\hline 1. & TAMIL & 85 & 98.27 & 15.488 & \multirow{3}{*}{300} & \multirow{3}{*}{1.893} & \multirow{3}{*}{.000} & \multirow{3}{*}{ S } \\
\hline 2. & ENGLISH & 215 & \multirow{2}{*}{101.46} & \multirow{2}{*}{12.116} & & & & \\
\hline 3. & TOTAL & 300 & & & & & & \\
\hline
\end{tabular}

The Table 3 shows that mean score difference in attitude towards homework among secondary level teachers based on medium of instruction. The calculated t-value is statistically significant at 0.05 levels and hence, the hypothesis 3 is accepted. It can be concluded that there is a significant difference in attitude towards homework among secondary level teachers based on medium of instruction. 


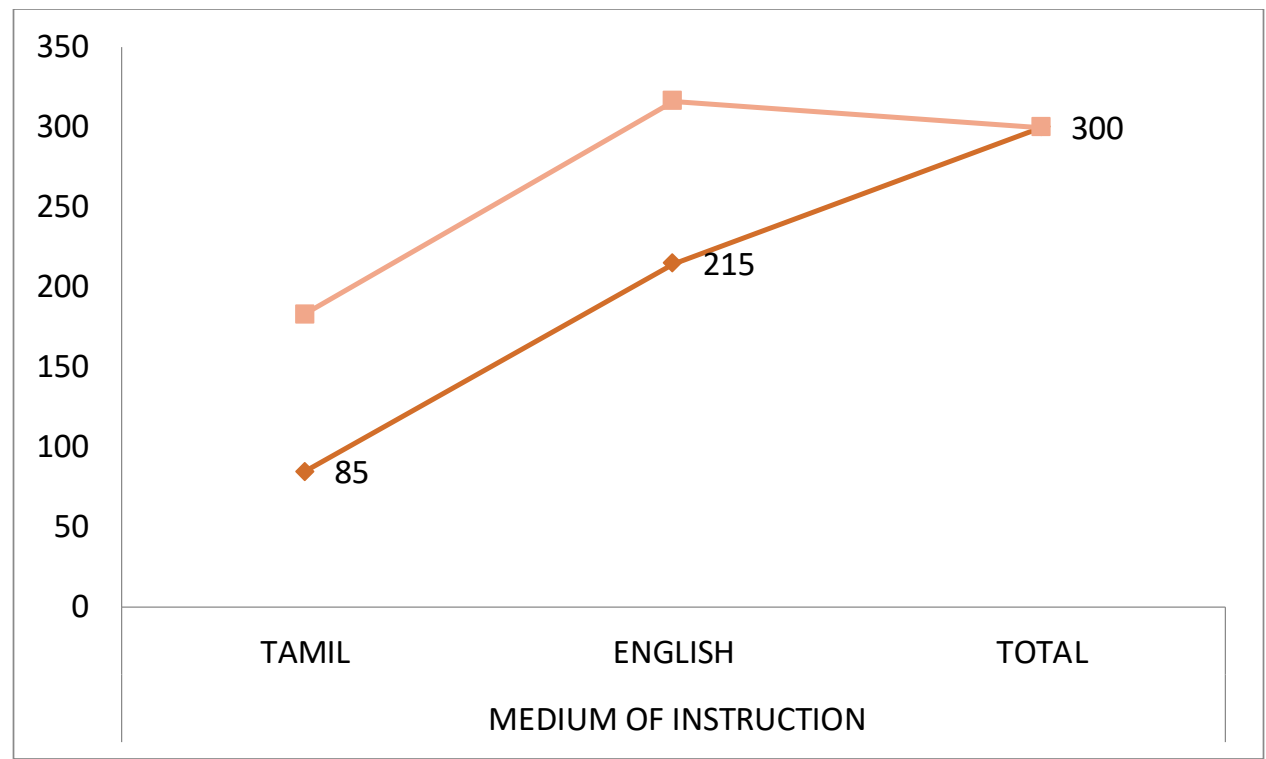

Chart 2: Mean Score Difference in Attitude towards Home Work among Teachers at Secondary Level Based on Medium of Instruction

\section{Conclusion}

The findings reveal that totally $24 \%$ of the teachers at secondary level belong to low level of attitude towards home work, $50.33 \%$ of the teachers at secondary level belong to moderate level of attitude towards home work, and $25.66 \%$ of the teachers at secondary level belong to high level of attitude towards home work. There is no significant mean score difference in attitude towards homework among secondary level teachers based on gender. It can be concluded that there is a significant difference in attitude towards homework among secondary level teachers based on medium of instruction. English medium students have better mean value than Tamil medium students. Thereby medium have strong influence in attitude towards home work.

\section{Reference}

[1] Arens, A. K., Yeung, A. S., Craven, R. G., \& Hasselhorn, M. (2011). The twofold multidimensionality of academic self-concept: Domain specificity and separation between competence and affect components. Journal of Educational Psychology, 103, 970-981. doi:10.1037/a0025047

[2] Eccles, J. S. (1983). Expectancies, values, and academic choice: Origins and changes. In J. Spence (Ed.), Achievement and achievement motivation (pp. 87-134). San Francisco: W. H. Freeman.

[3] Golden, S. A. R. (2011). Problems and Prospectus of Distance Education. Quality Enhancement In Distance Education For Life Long Learning, 1(1), 343-344.

[4] Golden, S. A. R. (2016). RURAL STUDENTS' ATTITUDE TOWARDS ENGLISH AS MEDIUM OF INSTRUCTION IN HIGHER EDUCATION - AN ANALYSIS. International Journal of Research, 3(Special Issue - 16), 1-10.

[5] Golden, S. A. R. (2017). Attitude of Students and Teachers towards E- Learning - An Analysis. Recent Research in Social Science \& Humanities, 1, 5-10.

[6] Golden, S. A. R., \& S, P. (2013). An Analysis Of Mental Stress In Heavy Alloy Penetrator Project, Tiruchirappalli. SELP Journal of Social Science, 4(14), 51-55. 
[7] Kackar, H. Z., Shumow, L., Schmidt, J. A. \& Grzetich, J. (2001). Age and gender differences in adolescents' homework experiences. Journal of Applied Developmental Psychology, 32, 70-77

[8] Marsh, H. W., Abduljabbar, A. S., Abu-Hilal, M. M., Morin, A., Abdelfattah, F., Leung, K., Xu, M. K., Nagengast, B. \& Parker, P. (2012). Factorial, convergent and discriminant validity of TIMSS math and science motivation measures: a comparison of Arab and Anglo-Saxon countries. Journal of Educational Psychology. doi:10.1037/a0029907

[9] Oostdam, R. \& Hooge, E. (2013). Making the difference with active parenting; forming educational partnerships between parents and schools. European Journal of Psychology of Education, 28, 337-351 doi: 10.1007/s10212-012-0117-6

[10] Regi, S. B., \& Golden, S. A. R. (2014). A Study On Attitude Of Employee Towards Working Environment With Special Reference To RR Pvt Ltd. Review Of Research, 2(2), 1-5.

[11] Riglin, L., Frederickson, N., Shelton, K. H. \& Rice, F. (2013). A longitudinal study of psychological functioning and academic attainment at the transition to secondary school. Journal of Adolescence, 36 (3), 507-517. doi.org/10.1016/j.adolescence.2013.03.002

[12] Trautwein, U., \& Lüdtke, O. (2007). Students' self-reported effort and time on homework in six school subjects: Between-students differences and within-student variation. Journal of Educational Psychology, 99(2), 432-444. doi:10.1037/0022-0663.99.2.432. 